theme 1 strand 2

design education in art, craft, technology, and other traditions

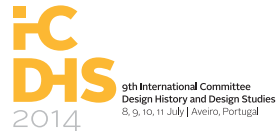

Blucher Design Proceedings Dezembro de 2014, Número 5, Volume 1

\title{
Together, but different: two co-occurring new degrees at the school of architecture in Antwerp
}

While the history of architectural education has already gained attention, the education of the subfields such as interior design, urban planning, conservation and restoration and product development, are hardly investigated in many countries including Belgium. Recently, a study of the architectural training at the Royal Academy of Antwerp published on its 350th anniversary, shed light for the first time on the education of the diverse subfields. This paper sets out to discuss the development of two new degrees in post-war Flanders which are most related to the discipline of design studies, viz. interior design and product development. Both were created at the Nationaal Hooger Instituut voor Bouwkunst en Stedebouw NHIBS [National Institute for Architecture and Urbanism] in Antwerp. Although education of Interior Architecture and that of Product Development were both rooted within the ideology of modernism, they have different origins. In both cases, the naming of the course entities was subject to much debate - even to contestation. The evolving nomenclature reveals a lot about the educational content and pathways.

keywords interior design, industrial design, education, product development, Antwerp

\section{Introduction}

While the history of architectural education has already gained attention (for example, among others, Ockman 2013; De Caigny and Van Impe 2012; Delevoy Robert, Culot and Van Loo 1979; Van Looij 1989, 302-319), the education of the subfields are not so much investigated in many countries including Belgium. A study of the history of the Royal Academy of Antwerp, founded in 1663 by painter David Teniers to the model of the Accademia di San Luca (1588) in Rome and the Académie royale de peinture et de sculpture (1648) in Paris, changed that (De Vos and Lombaerde 2013). The unbundling of the architecture school Nationaal Hooger Instituut voor Bouwkunst en Stedebouw NHIBS [National Institute for Architecture and Urbanism] from the Royal Academy of Fine Arts in 1946, had acquired a momentum of its own, causing a dynamic to think about new degrees, viz. urbanism, conservation of monuments and sites, interior design and product development. The aim of this article is to discuss the development of two new degrees in post-war Flanders, viz. interior design and product development. Both were created at the NHIBS in Antwerp and both were rooted within the ideology of modernism, but they had different beginnings.

\section{The development of interior architecture}

In the postwar period, several educational programs in interior architecture were launched in Belgium, as well as in other Western countries. In 1946 the Royal Academy of Antwerp 
theme 1

theory

Figure 1.

cupboard

designed and painted by Claire Bataille under the supervision of $\mathrm{R}$. Van Tenten (195657), photographer: Stephan Peleman, Archive of Interior architecture Antwerp. strand 2

design education in art, craft, technology, and other traditions

created the first degree in interior architecture in Belgian Flanders, called Binnenhuiskunst -literally the "art of the domestic interior". Other programs soon followed, such as the Royal Academy of Ghent in 1947 and the competing architectural school Saint Lucas in Ghent in 1949 (Nevejans A., a.o., 2012; Van De Perre 2003, 81). The degree in Antwerp was the icing on the cake of an evening course interior design that was organized for men at the Antwerp 'avondschool voor kunstambachten' [Evening school for arts and crafts] in 1941. The male target group is quite exceptional as mostly, interior design classes are, other than architectural classes, organized for women (Van De Perre 2003, 22; Ockman 2013, 324-325; Lytken 2013). The motive for the course in Antwerp was to keep the Belgian men out of the hands of the German army. On the other hand, it would take until the mid-1980s when women started to dominate the student population of interior architecture. Two former students of the Royal Academy of Antwerp, architects Jul De Roover and Paul Smekens, were attracted in 1941 to teach the evening course for free. After the war, De Roover could convince the director of the NHIBS in Antwerp to organize the first fully-fledged degree in interior architecture in Flanders. The duration of the study lasted five years and was reduced to four in 1964. De Roover was initially the only in charge of the practice-based part of the programme. From 1950 onwards, he was supported in this capacity by the architect Rob Van Tenten (Fig. 1).

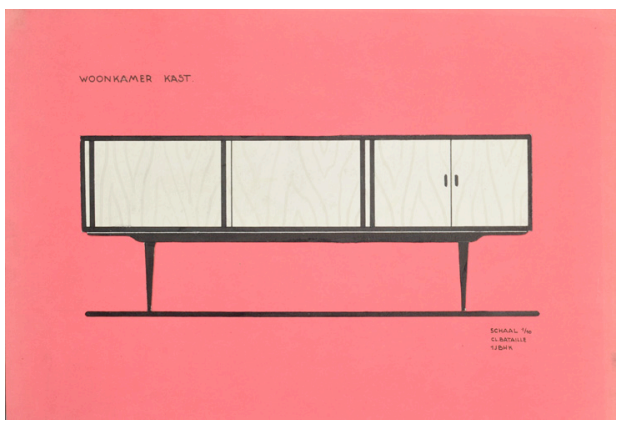

Although interior design as an autonomous discipline was only taught in the postwar period, its roots can be traced back to 1848 when a new branch of studies in the Decorative Arts was introduced for the first time in Belgium at the Antwerp Academy of Fine Arts. These new courses were intended to meet the needs of craftsmen and artisans who had suffered from the abolition of the guilds and corporations (Prina 2013, 74-75). These courses were linked to the three major arts - painting, sculpture and architecture - and comprised all the disciplines related to architectural design, such as stone cutting, carpentry, furniture design, etc. The decorative arts courses, given by architect Franz Durlet, were at the origins of today's 'design' and contributed to the birth of the Gesamtkunstwerk that was already developed before the Art Nouveau (Prina 2010).

In the inter-war period, architect Victor Horta who was head of the design studios at the Academy from 1919 to 1927, included interior design in his training. His own commissions at that time, including the Palais des Beaux-Arts in Brussels (1919-1928), acted as a model and were used to discuss their organization and interior design (Jaenen 2013, 90). He also gave the course 'ameublement' (furnishing) in which he discussed several pieces of furniture as well as other objects such as vacuum cleaners, lightings or radiators. Functionalism and sobriety in the design were some of the key elements in his courses, although he refrained from imposing a particular style. Stylish furniture as well as modernist furniture were studied under his guidance. (Jaenen 2013, 90) 
All of this changed from 19410nwards, when De Roover set up the courses of interior design. Modernism was much more present. This is not surprisingly as De Roover was a member of the Belgian branch of the Congrès Internationaux d'Architecture Moderne CIAM, an admirer of Charlotte Perriand and the brother-in-law from architect Renaat Braem who had been an apprentice of Le Corbusier during 1936-37 (De Vos 2010). That on its turn influenced the interior design training programme. However, as European modernism was losing its legitimacy in the post-war period, De Roover was not dogmatic. He wrote for example:

"A good home is not a machine for living; [...] in first instance we should create a living environment where we gather with relatives and friends, where we show our personality, where the small enjoyments of life, such as flower arrangement, placing and hanging art objects and knick knackery reproduces the character of the inhabitants to the interior." (De Roover s.d., APA).

The anthropological term 'habitat' became important to explain the objectives of the courses in interior design. De Roover was already in January 1952 informed about the Chartre d'Habitat in preparation for the CIAM IX in 1953. With this term, he indicated that the (interior) architect should include the whole living environment of his clients, from furniture and interior all the way down to the urban plan.

From the same token, De Roover fought for a better position and career prospects for the interior architect. Unlike the diploma in architecture, which was equivalent to a university degree, the first graduates of interior architecture received a certificate of technical secondary level. That changed on 8 January 1969, when De Roover and the then director, Frans De Groodt, obtained that the diploma was recognized as a higher education qualification in art studies. A precondition for that upgrading, was the change of the title from Binnenhuiskunst [art of the domestic interior] to "Binnenhuisontwerpen" [Domestic Interior Design] in 1955. However, the Architects' Association prevented the inclusion of the suffix "-architecture" in the professional title because the title of architects was protected by law since 1939. Eventually, De Roover went to court and was granted the right to use the name "Binnenhuisarchitect" [domestic interior architect] to the example of their colleagues in the surrounding countries. (Laporte 1996, 9) The new title further underscores the discipline and highlights that the training goes beyond interior decoration. Later, "domestic" would leave the title as the profession did not limit itself to domestic spaces, but dealt with public interiors as well, and that had to be noticed in the title.

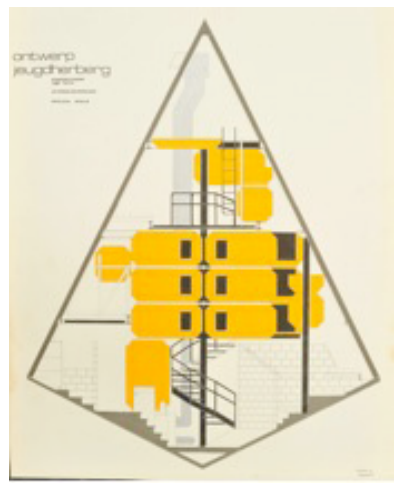

Figure 2. a youth hostel, master proof of Steven Stals under the supervision of J. De Roover (197273), photographer: Stephan Peleman, Archive Interior architecture, Antwerp. 


\section{The emergence of Industrial Design}

While interior architecture branched off as an architecture specialisation, that was not the case with Industrial Design. The creation of a degree in 'Industrial design' has other roots. It was formulated as follows:

"According to developments in the education of 'machine drawing' in other countries, the board of directors of the institution [the NHIBS] is busy with the foundation of a special division to educate Industrial Designers, to which our industry is insisting upon." (Ministerie 1954: 667).

However, it took more than a decade before the branch of Industriële Vormgeving was really set up as the first education in Industrial Design in Flanders. (De Groodt, 1976) Probably it took so long because industrial design was a quite new discipline in Belgium - in 1957, the first year started in Brussels while in 1964, another followed in Liège - and experience was lacking. Moreover, the Belgian Institute for Industrial Design warned in 1968 for the ease with which the new courses were set up. At the same time Ray Gilles, who taught colour theory at the NHIBS between 1967 and 1976, warned for the fact that the industry was not ready for industrial design as they could not distinguish industrial design from arts and crafts (Serulus 2013, 178).

The first endeavours to set up a new programme by architect Willy van der Meeren, amongst others, were not successful (Ministerie van Nationale Opvoeding en Cultuur 1966, 28-30). That changed when designer Jean-Jeacques Stiefenhover (1943-2013) was attracted to develop a new programme. He had just finished his studies at the renowned Hochshule für Gestaltung in Ulm founded in 1953. As a consequence, the new programme in Antwerp was inspired by the famous Ulmer model that on its turn was based on the pedagogic Bauhaus tradition, as the first director Max Bill was an old student of the Bauhaus. Other inspirational programmes were those at the Technische Hogeschool in Delft, the Royal College of Art in London and the Pratt Institute in New York. A multidisciplinary approach of design, including applied sciences, mathematics, human and social sciences and design studios, formed the basis of a global design methodology. This model is also called a holistic approach of design or design thinking. (Baelus 2012)

The new orientation of the programme became visible under its new name: Industriële Vormgeving [Industrial Design] was replaced by Productontwikkeling [Product development]. As such, they wanted to avoid associations with artists or with a light version of an engineer training. (Serulus 2013, 179) Indeed, the term Industriële Vormgeving was often added to the name of the craftmanship schools, but lacked any content. The name Productontwikkeling however, referred to the American term product development, coined by the famous Igor Ansoff, the father of Strategic management. Product development indicated the complete process of bringing a new product to market. As such, not only the design of the product was taken into account, but the whole process from market research and market analysis to the life cycle of the product after it has been laced on the market. Product life cycle management is included and considered essential to maintain or grow the market share. It is still an important part of the course that distinguishes the programme in Antwerp from others in Flanders. 


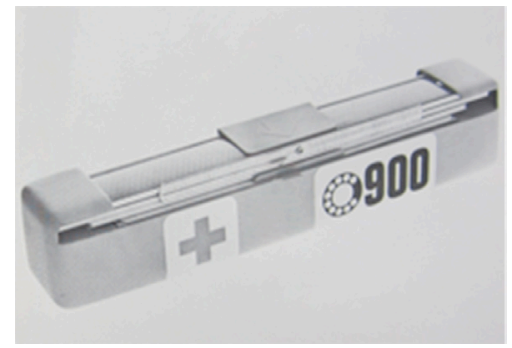

Figure 3 . aid kit for cars, designed by $\mathrm{H}$. Anrig, M. Billet, V. Goyvaerts, G. Patfoort and P. Tahon (1976), in: F. De Groodt 1976, 27; Library of Heritage Hendrik Conscience.

\section{Conclusion}

Education in Interior Architecture and in Product Development were both founded in the post-war period and rooted within the ideology of modernism, but have different origins. Interior Architecture branched off as an architecture specialisation, but can be traced back to the Decorative Arts, which for the first time was taught in Belgium at the Antwerp Academy of Fine Arts in 1848. Despite these ancient roots, the contents of the interior architecture course was mainly influenced by the contemporaneous evolution in architecture, more in particular the developments at the CIAM and Team X. That was due to the influence of its professor Jul De Roover, which was a modernist and involved in the Belgian CIAM branch.

The incentive for the establishment of a degree in Product Development originated from the industry and was stimulated by similar courses abroad. Especially the school of Ulm that on its turn was based on the pedagogic Bauhaus tradition, was very influential. Substantially more than in architecture, the design of a product is not the single focus, but only one aspect in the process of the development of a product that starts from market research to the monitoring of the product after purchase.

The nomenclature of the course entities was subject to much debate in both cases. The redesign of the titles was a way to improve the prestige of the profession and its education. In interior architecture, the evolution from Binnenhuiskunst to Interieurarchitectuur went hand in hand with an expansion of its field from the domestic interior to the interior of public buildings, and from a more artistic approach to a more abstract and technical scale influenced by modernism (architecture). A similar evolution can be traced in the changed nomenclature of Productontwikkeling. While Industriële Vormgeving suggested more associations with applied art and the skilled trades, Productontwikkeling has more scientific associations as it relies more on management, social sciences, economics, sociology, ergonomics, etcetera.

\section{References}

Baelus C. (2012), interview carried out by Katarina Serulus, 7/03/2012, Antwerp. De Caigny, S. and Van Impe, E. (2012) Bronnengids architectuuronderwijs Vlaanderen, VAi, CVAa: Antwerpen.

De Groodt, F. (1976) Produktontwikkeling, NHIBS: Antwerpen.

Delevoy R. L., Culot and Van Loo A. (1979) La Cambre.1928-1978, AAM: Brussel.

De Vos, E. and Lombaerde, P. (2013) Van Academie tot Universiteit. 350 jaar architectuur in Antwerpen, UPA: Antwerpen.

Jaenen, M. (2013) 'De discussie rond de architect als kunstenaar (1919-1936)', in De Vos, 
E. and Lombaerde, P. (ed.) Van academie tot universiteit, UPA: Antwerp, pp. 88-99. Laporte D. (1996) 'Van Binnenhuiskunst naar Binnenhuisontwerpen', in Laporte D., Kieckens C., Thijssen J., a.o., 50 jaar interieurarchitectuur Antwerpen, Antwerpen: Handelsbeurs, pp. 7-12.

Lytken M. (2013) 'The Danish School of Interior Architecture', Journal of Interior Design, vol. 38, no. 3, 1-19.

Ministerie van Nationale Opvoeding en Cultuur (1966) Nationaal Hoger Instituut voor bouwkunst en Stedebouw 1966, Antwerp: NHIBS.

Ministerie van Openbaar Onderwijs (1954) Driejaarlijks verslag 1951-1953, Brussel. Nevejans A., Van Impe E. and Van de Voorde S. (Dec. 2012/ Sept. 2010) Koninklijke Academie voor Schone Kunsten, Gent (1751-). In ODIS - Database Intermediary Structures Flanders [online]. Record no. 5864. Available from http://www.odis.be.

Ockman J. (2012) Architecture School. Three centuries of educating architects in North Amercia, Cambridge, Massachusetts, London, England: MIT Press.

Prina D.N. (2010) 'Design in Belgium before Art Nouveau: art, industry, and the reform of artistic education in the second half of the nineteenth century', Journal of Design History, vol. 23, no. 4, pp. 329-350.

Prina D.N. (2013) 'Architectuuronderwijs aan de Antwerpse Academie voor Schone Kunsten, tussen traditie en innovatie (1831-1914)', in De Vos, E. and Lombaerde, P. (ed.) Van academie tot universiteit, UPA: Antwerp, pp. 70-87.

Serulus K. (2013) 'Van industrial design tot productontwikkeling', in De Vos, E. and Lombaerde, P. (ed.) Van academie tot universiteit, UPA: Antwerp.

Van De Perre D. (2003) Van twee werelden, Provinciebestuur Oost-Vlaanderen: Wetteren. Van Looij, T. (1989) 'De Antwerpse Koninklijke Academie voor Schone Kunsten', in Boschloo, A. W. A., a.o., Academies of Art, Den Haag, pp.302-319.

\section{Archives}

Archive of Jul De Roover, Architecture Archive of the Antwerp Province APA. 